\title{
Balancing Performance by Human Resource Management Practices
}

\author{
Mahmoud Manafi ${ }^{1} \&$ Indra Devi Subramaniam ${ }^{1}$ \\ ${ }^{1}$ GSM, Multimedia University, Malaysia \\ Correspondence: Mahmoud Manafi, GSM, Multimedia University, Malaysia. E-mail: \\ mahmoud_manafi@yahoo.com; indra@mmu.edu.my
}

Received: November 14, 2014

doi:10.5539/ass.v11n10p386
Accepted: February 3, 2015 Online Published: April 21, 2015

URL: http://dx.doi.org/10.5539/ass.v11n10p386

\begin{abstract}
One of the most famous concepts in strategic human resource management (SHRM) is human resource management (HRM) practices. Various researches by famous scholars have shown that HRM practices have the potential to affect organizational performance. Besides, performance of an organization has different aspects for example balanced scorecard (BSC) considers four perspectives for performance and they are Financial, Customer, Internal Process and Learning and Growth.

However, companies aim to balance performance of the HRM practices based on their goals, so they need to know the intensity of implementing each practice. In this regard, this study attempts to forecast the impact of each group of practices on organizational performance (BSC's perspectives) before implementation. For this purpose, Artificial Neural Networks (ANN), Analytic Hierarchy Process (AHP) and Fuzzy Logic will be used in combination. In other words, this combination will highlight the most proper group of HRM practices for the desired performance.
\end{abstract}

Keywords: HRM practices, organizational performance, BSC, neural networks, AHP, fuzzy logic

\section{Overview}

Strategic human resource management (SHRM) has advanced greatly since the 1980s (Lepak \& Shaw, 2008). Research into this area has demonstrated and proved the connection linking human resource management (HRM) techniques and accomplishment in different areas (Dyer \& Reeves, 1995). Some examples showing the positive effects of HRM techniques have contributed to employee retention (Huselid, 1995; Guthrie, 2001; Batt, 2002; Sun et al., 2007), increased stock returns (Collins \& Clark, 2003), better organizational citizenship behavior (Sun, Aryee, \& Law, 2007), higher labour productivity (Huselid, Jackson, \& Schuler, 1997; Youndt, Snell, Dean, \& Lepak, 1996; Huselid, 1995; Guthire, 2001; Sun et al., 2007), higher sales growth (Collins \& Clark, 2003),better financial performance (Huselid et al., 1997; Huselid, 1995) more efficient operational performance (Youndt et al., 1996, Batt, 2002; Colins \& Smith, 2006), and higher revenue from new products and services (Collins \& Smith, 2006).

Notably, academics looking into this area have demonstrated that an HR system is an appropriate level of theory and analysis. In the meta-analysis by Combs, Liu, Hall, \& Ketchen (2006), HRM practice systems were shown to produce greater improvements on organizational-level performance than individual HRM practices. Combining multiple HRM practices into a coordinated system is acknowledged as a methodology to assess the cumulative or synergistic effects among the interrelated HRM practices (Combs et al., 2006; Delery, 1998; Huselid, 1995; MacDuffie, 1995).

In addition to the ever-increasing substantiation of the direct linkages between HRM practices and organizational performance, academics looking into HRM have frequently looked more and more at the ways HR system practices boost organizational performance. Research in this area has highlighted various transitional results. As just one example, it is realized that turnover (Huselid, 1995; Batt, 2002), organizational corporate behavior (Sun et al., 2007), group human capital (Takeuchi, Lepak, Wang, \& Takeuchi, 2007), environments for cooperation, trust, senior managers' social networks (Collins \& Clark, 2003) and shared codes (Collins \& Smith, 2006) mediate a relationship that is positive between HRM practices and performance at the organization-level. Boxell, Purcell, and Wright (2007) divided human resource management into three distinct secondary classifications namely micro human resource (MHRM), strategic human resource (SHRM), and international human resource (IHRM). HR strategies should be more concentrated as it deals with the measurement of the impacts on the 
performance level of organizations and since it is associated with SHRM, it is also being used by businesses in their organizations. Lengnick-Hall et al. (2009), after three decades of researching on this area, have identified and introduced 7 main themes for HRM as shown in Table 1 below.

Table 1. Seven themes of HRM in past three decades

1. Contingency Perspectives and fit

2. Shifting from a focus on managing people to creating strategies contributions

3. Elaborating HR system components and structure

4. Expanding the scope of SHRM

5. Achieving HR implementation and execution

6. Measuring SHRM outcomes

7. Evaluating methodological issues

Source: Lengnick-Hall (2009)

Based on the table above, in the second theme, there are several areas of interest such as HRM practices, Human capital, Social capital and Resource Based view (Barney, 1991). These contributions have been argued widely by other researchers such as Barney and Wright (1998), Leana and Van Buren (1999), Boxell and Purcell (2000), Wright, Dunford, and Snell (2001), and Ahmad and Schroeder (2003). The emphasis has been on making sure that the employees have the motivation and abilities to reach the overall organizational targets and objectives.

Organizational performance may depend on structure and a firm's objectives. For example, Kaplan and Norton (1992) considered four perspectives for performance including Financial, Internal Process, Learning and Growth, and Customer.

While a quartet of perspectives for organizations is set out in the Balanced Scorecard by Norton \& Kaplan (2000), a company may choose not to develop in all four areas. Charity organizations, for example, may not aim to grow financially. Besides, priority of each of the perspectives may be different in different organizations. (It is presented with some examples in their book (Note 1)).

Furthermore, experts believe that human resource management could be basic to the performance of the firm covered by the main competence, ability of the organization, intellectual issue, and better performance of system of work, management steps, the group of value features and the group of better performance (Ulrich et al., 1997, p. 1).

Contemporary papers have considered areas such as: HRM practices concerned with increasing an organization's performance and revenue (Huselid, 1995), return on equity and assets (Delery \& Doty, 1996), profit of labour (Datta et al., 2003; Youndt et al., 1996; MacDuffie, 1995; Huselid, 1995), and margin of profit (Kalleberg \& Moody, 1994). Much of these investigations into HRM influence on a company's performance can be applied to other organizations (Ichniowski, 1990; Huselid, 1995; Wyatt's, 2002; Davision et al., 1996). Organizations therefore are looking for benefit from human resources management practices. The form of benefit may differ for different companies.

Based on previous research, HRM practices have the potential to affect organizational performance, but the intensity of implementation of each practice needs to be determined. Wright et al. (2003) coded implantation of each practice with binary system (implantation of each practice 1 and no implementation with zero). Organizations may have weakness in implementing some practices, but their method is not capable of showing the intensity of each practice.

Following the above discussion, if four perspectives are considered for performance (BSC's perspectives), each HRM practice may affect more than one perspective of performance at the same time. Hence, the main purpose of this study is to find which group of HRM practices should be applied for balancing performance based on organizational goals.

The most prevalent gaps that appear beckon the answer to "which HRM practices should be implemented to meet organizational goals?" and among all the various sets of practices, "which set can be easily adopted alongside the objectives of the organization?" Given this glaring challenge, many firms and even researchers are faced with problems in deciding on the most appropriate practices to be used or researched. This challenge is made worse by the fact that to date, there has not been a consensus on which are the best HRM practices to be 
adopted (Yanzhen et al., 2010). Moreover, Chhinzer and Gurdeep (2009) added that every firm must reassess its corporate level objectives, strategies, vision, and operations in order to transform their human resources. The discussion on the best way to allow HRM practices to be aligned with corporate goals then becomes prevalent.

\section{What HRM Procedures Are Successful?}

Wylie (2005) and Wang and Shyu (2008) stated that alignment between business and HRM strategies is the paramount issue for success in organizations. Companies in which HRM and commercial strategies were aligned were found to have more effective HRM practices and organizational performance than those firms in which the strategies were not affiliated. In Australia, research by Zheng et al. (2007) also demonstrated the connection between strategic HR and an organization's strategies and identified the impact of strategic HR on organizational performance.

Uysal, (2008) examined the relationship between the success of a company and its HRM practices. He found that HRM practices have an influence on the overall performance of the organization. It was found that issues such as staffing, compensation, training, and promotion were of great concerns and influenced the firm as well as the market performances. In a survey of heads of Australian firms in terms of HR priorities, trends, and challenges, Astor Levin (2009) highlighted three main areas which are:

1) Tactics to retain staff.

2) Continuing "right sizing" or downsizing.

3) The need to invest in employees.

In the Eleventh Annual Global CEO Survey (PWC, 2009) by Price Waterhouse Cooper, some leading features for HR Professionals to take note of were:

- The relationship between employees and firm profit;

- The influence of HR policies and procedures on the overall business strategy and revealing in financial terms how the HR strategy helps the business operations;

- The initiative to effectively measure the return on investment (ROI) of HR strategy; and

- Seeing the HR unit as the 'steward' and key enabler of the firm's valuable employees and not just as a business partner.

In 2008, Uysal stated that human capital improves learning through doing, thereby reducing a company's expenditure and producing a competitive advantage.

This shows that the work carried out by the HR unit in managing an organization's human capital (the collective knowledge, skills and abilities of the staff) is very important. Other forms of capital can be bought and technology can be imitated but the uniqueness of the human capital can be a sustainable competitive advantage for the firm (Kulik \& Bainbridge, 2006; Hebert, 2004).

Firms, in which communication is effectual, have been shown to prosper better than similar ones in the same industry. Dialogue among senior leaders and employees is promoted in exceedingly successful companies. Often supervisors and frontline managers highlight crucial messages, collect staff feedback and establish individual goals that align with corporate aspirations (Finney, 2008).

\section{Performance Measurement and BSC}

From the review of literature, it was found that there are many concepts regarding the evaluation of performance that investigates the various dimensions but in sum, there are two perspectives regarding the evaluation of performance: modern view and traditional view (Hojabri, 2011). In the modern perspective, the philosophy of evaluation is embraced and the philosophical effect on development is accepted while in the traditional perspective, the main objective is performance evaluation and judgment. Other related variations are caused by several direct factors that affect the result of the evaluation; for instance, the evaluator's function in the traditional perspective is based on judgment while in the modern perspective, the idea is linked to the operation of the consultant and the facilitator's performance. The next factor is the duration of the evaluation. Based on the traditional perspective, it is based on the past performances and in the modern perspective, it is the future improvements that can be found in the portfolios. The figure below highlights these variations. 
Table 2. Traditional and modern concepts in performance evaluation

\begin{tabular}{|c|c|c|}
\hline Key factors & Traditional Concept & Modern Concept \\
\hline Role of evaluator & Judgment and performance measurement & $\begin{array}{l}\text { Consultant and facilitator for further } \\
\text { performances }\end{array}$ \\
\hline $\begin{array}{l}\text { Duration } \\
\text { evaluation }\end{array}$ & Previous & Future performance \\
\hline & & Self-standardize \\
\hline Evaluation standards & $\begin{array}{l}\text { Benchmarking-using experience } \quad \text { of } \\
\text { successful managers and organizations }\end{array}$ & $\begin{array}{l}\text { Customize standards, measurements } \\
\text { with the organization structure }\end{array}$ \\
\hline Aim of evaluation & Controlling the organization & $\begin{array}{l}\text { Growth and development of the } \\
\text { organization }\end{array}$ \\
\hline Output of evaluation & Performance controlling & Performance improvement \\
\hline $\begin{array}{l}\text { Feedback } \\
\text { evaluation }\end{array}$ & $\begin{array}{l}\text { Finding successful managers and giving } \\
\text { them motivation }\end{array}$ & $\begin{array}{l}\text { Consultant for continuing improvement } \\
\text { and creating quality improvement }\end{array}$ \\
\hline $\begin{array}{l}\text { Method of analysis } \\
\text { after evaluation }\end{array}$ & Disciplinary Environment & Cooperation environment \\
\hline
\end{tabular}

Source: Hojabri (2011) Balance scorecard: New tool for performance evaluation and competitiveness improvement

Performance Evaluation is a contemporary concept that varies a great deal in several aspects from the conventional method. The contemporary notion of performance evaluation aims to achieve and enhance satisfaction, performance, and effectiveness in the organizational processes. The contemporary concept is a generally accepted perspective in government department particularly in countries in the European block. Many of these organizations conduct researches to find out the best method to evaluate performance and are convinced that this modern approach is more beneficial. Even though it is very beneficial, however some conditions for it to work well need to be considered. If the performance evaluation aims to relate its objectives to the organizational plans, then, it must involve more than just the evaluation of employees. Employees should be involved in the implementation of such an evaluation and continuous effort should be taken to improve the performance evaluation. Eventually, self-evaluation can take place and a new and significant culture that meet the organization's objectives can emerge.

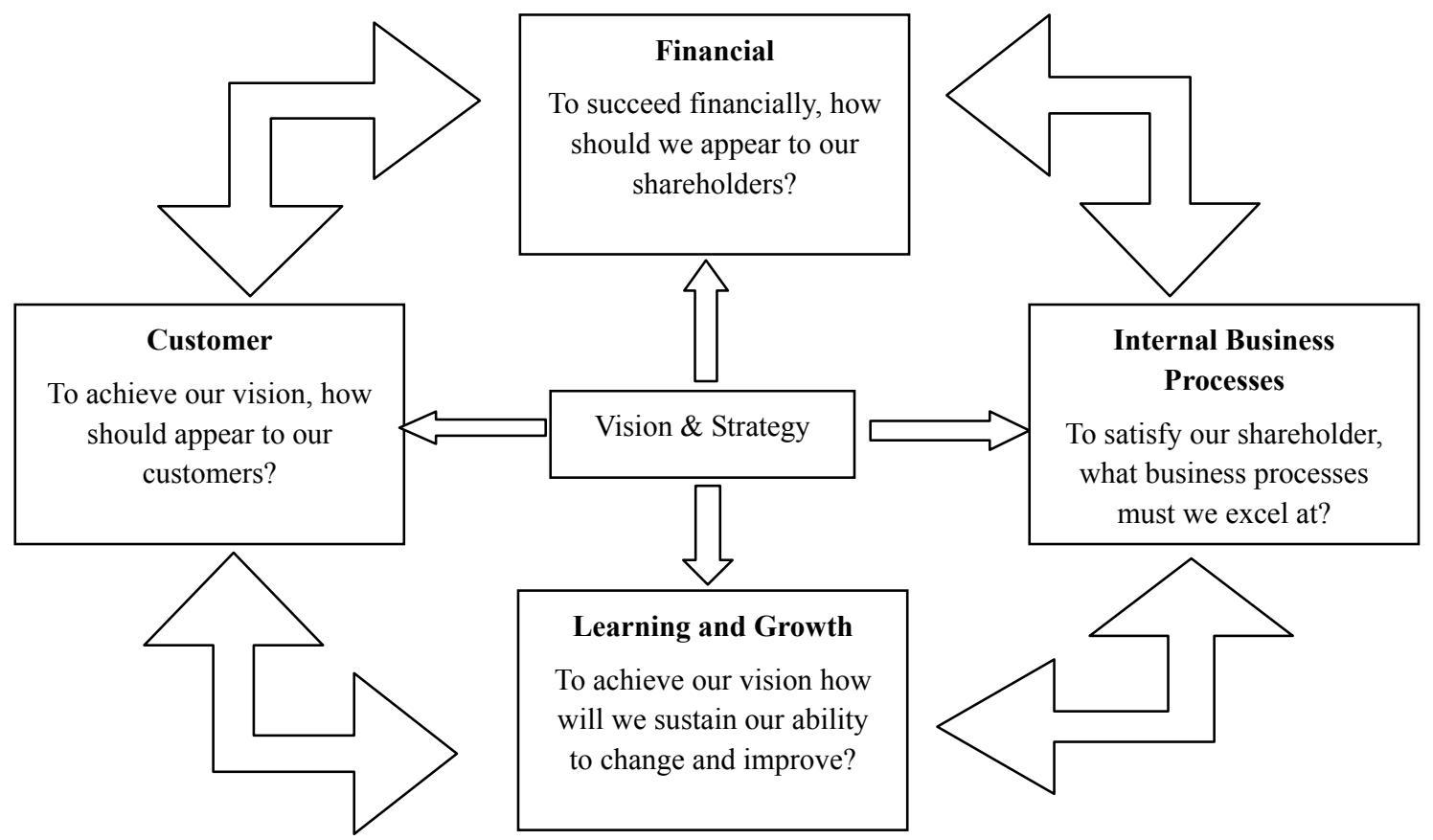

Figure 1. The balance scorecard by Kaplan and Norton (Source: Kaplan and Norton, 1992) 
The Balance Scorecard (BSC) method is one of the most popular tools in strategic performance management. In this method by Kaplan \& Norton (1992), any organization can be considered from four dimensions: financial, learning and growth, customer, and internal process. Before BSC, the main focus of organizations was the financial dimension. Following the creation of Balanced Scorecard, dimensions apart from the financial were also given attention (Figure 1).

This model concentrates on a conceptual outline in measuring the performances based on the strategic objectives; after which the performances are evaluated alongside the strategic objectives. It is a prerequisite that the organization has its vision, mission, and values recorded prior to this exercise. Following this, reflecting on the mission and vision of the organization, the strategic objectives are planned out and critical success factors are defined. In the end, the management will be able to evaluate the performance of the organization based on the strategic objectives and subsequently reach to reach its potential. This model is especially effective in evaluating performance and matching it with the strategies of the organization (Hojabri, 2011; Aghababa, 2010).

\section{Methodology}

This section justifies all the necessary methods for this study. In this regard, three main mathematical methods are presented, and they are Fuzzy Logic, Neural Networks, and AHP. As a matter of fact, the method of this study applies a combination of these three mentioned methods based on the capability of each method.

\subsection{Mathematical Methods}

\section{Fuzzy Logic}

The term fuzzy logic was first used by Zadeh (1965) (cited by Zimmermann, 2001), who combined the two contradicted words to define the term. The definition is based on "set theories" which describe the membership of an element within a set in a different way (challenging the membership). For example if $X=\left\{x_{1}, x_{2}, \ldots, x_{n}\right\}$ and $A=\left\{x_{1}, x_{2}, \ldots, x_{k}\right\}$ was a subset of $\mathrm{X}$, membership of $x_{1}, x_{2}, \ldots, x_{n}$ could be written as per the following function:

$$
\begin{aligned}
& f_{A}: X \rightarrow\{0,1\}, \\
& x_{1} \rightarrow 1, \\
& x_{2} \rightarrow 1, \\
& x_{3} \rightarrow 1, \\
& \vdots \\
& x_{k} \rightarrow 1, \\
& x_{k+1} \rightarrow 1, \\
& \vdots \\
& x_{n} \rightarrow 1,
\end{aligned}
$$

But he replaced $\{0,1\}$ to $[0,1]$, so it allows every member of $X$ to have the membership degree between 0 and 1 . For example $f_{B}$ shows another subset of $\mathrm{X}$ that every element of $\mathrm{X}$ can have membership degree between 0 and 1.

$$
\begin{aligned}
& f_{B}: X \rightarrow\{0,1\}, \\
& x_{1} \rightarrow 1 / 2, \\
& x_{2} \rightarrow 1 / 3, \\
& \vdots \\
& x_{k} \rightarrow 1 / 4, \\
& x_{k+1} \rightarrow 0, \\
& \vdots \\
& x_{n} \rightarrow 1 / 5,
\end{aligned}
$$

And $\mathrm{B}$ as a fuzzy subset of $\mathrm{X}$ can be written as follows: 


$$
B: \frac{x_{1}}{1 / 2}+\frac{x_{2}}{1 / 3}+\ldots+\frac{x_{k}}{1 / 4}+\frac{x_{k+1}}{0}+\ldots+\frac{x_{n}}{1 / 5}
$$

After the definition of Zadeh, other scholars extended the [0,1] to lattices. (Zimmermann, 2001)

The most important algebraic structure $(L, \vee, \wedge)$ is Lattice which includes a set of $L$ and two duplex operations $\vee$, and $\wedge$.The following conditions for all factors $a, b, c$ of $L$ must be met for satisfying a Lattice structure.

$a \vee b=b \vee a$ Commutative laws

$(a \vee b) \vee c=a \vee(b \vee c)$ and $(a \wedge b) \wedge c=a \wedge(b \wedge c)$ Associative laws

$(a \wedge b) \vee a=a$ and $(a \vee b) \wedge a=a$ Absorption laws

The following two identities are also usually regarded as axioms, even though they follow from the two absorption laws taken together (Burris et al., 1981).

$(a \vee a)=a$ and $(a \wedge a)=a$ Identity laws

Example: the set $X=\{0,1,2,3,4,5,6\}$ with maximum $(v)$ and minimum $(\wedge)$ is a lattice can be replaced with $[0,1]$.

AHP Method

Saaty (1977, 1980, 1988, and 1995) had expanded one of the best significant Multiple Criteria Analysis (MCA) approaches which is called AHP (Analytic Hierarchy Process). By this method, researchers are able to measure and estimate the comparative weight of multiple options in a clear manner. Regarding the inaccessibility of quantitative rating, appraisers and policy makers are able to identify whether one criteria is more crucial than the other. Hence, pairwise comparisons are used.

Saaty (1990) identified a method for representing such pairwise comparisons ( $\mathrm{Y}$ is less important than $\mathrm{X}$ ) into a set of figures and digits which illustrate the relevant and respective superiority of each of the criterion.

The basic method to conduct the AHP includes the following steps:

1) Organizing the structure of the decision problem and criteria selection

The first step is to separate the decision problem into various selector segments. The most complete method to structure a decision problem is to divide the structure into two levels namely the highest level and the lowest level. The highest level contains the criteria and sub criteria; the lowest level contains the various options.

When all the segments are structured in a hierarchical format, it is easier for the decision makers to have an overall perspective of all the relationships and to examine the importance of each level comparing it to the next. Each element in a level is not required to operate as a scale and for all the other elements in the subsequent levels. At every level, a varied look of the problems is given and the hierarchy does not have to be complete (Saaty, 1990).

The hierarchies are constructed by considering the environment where the problem is located and areas that can be used as solution so that all the members involved can relate to the problem at hand.

2) Using Pairwise Comparison (weighing) to Prioritize the Settings of the Criteria

In deciding each pair of criteria, one has to examine and answer to the question as it appears below:

How important is criterion $\mathrm{X}$ compared to criterion $\mathrm{Y}$ ?

In order to rate the comparative importance of the criterion, a weight measurement is assigned to the more important criterion. The measurements are from 1 to 9 whereby 1 reflects equal importance while 9 reflects, highest importance. After assigning the appropriate weights to each criterion, the assessments are normalized and the average is measured for each criterion.

\section{3) Pairwise Comparison on each Criterion (Scoring)}

For pairing each criterion, the best known option is granted a score. Again, this score is categorized from 1 to 9 , where 1 shows "equally good" and 9 represents "absolutely good" scores among the criteria. Moreover, each score registers how well option "X" meets criterion "Y". After scoring, all assessments are normalized and averaged in order to get a score for each criterion.

According to Saaty (1990), the pairwise analogy of the items shows that they are homogenous or that they are near the common feature; if not a meaningful error could happen in the process of measurement. 


\section{4) Getting an Overall Relative Score for Each Option}

The final step with a combination of all the scores and weights from the criteria will reveal the general score of each option that is given. The comparative important criteria are found after the weighed summation is carried out by observing the options.

After evaluating the impacts of all the elements and entering the priorities of the hierarchy, the less important elements cease to exist from the list given their comparative low influence of the overall goals. After that, the priorities are again entered, by either changing or not changing the evaluation (Saaty, 1990).

In some cases, it is important to note that sustainability matters in repair ability among criteria can be challenging. To weaken the nature of AHP or MCA approach, the concept of "wants" and "musts" must be designed. When an option fails to meet the "musts" concept, it is known as infeasible. The other options are evaluated according to how successfully they address the "wants".

AHP is able to successfully assist in decision making especially in complicated sustainability matters and is able to identify and describe the details of a problem. It is commonly utilized to break down a decision problem into various steps, which are hierarchically structured. Conflicting or multiple objectives can be considered in this evaluation approach. In addition, the paired comparison method makes the decision makers to evaluate each trade-off individually and this is a long process. Consequently, AHP offers the options a ranking that helps the selection of a policy. AHP is not very appropriate for the evaluation and implementation of implemented policy methods.

\section{Sustainability Aspects}

For comparing long-term effects of elements, the most important method is AHP which is able to do so. The incorporated criteria for comparing alternative policies are the aspects which are sustainable, as examples: adaptability, (de-) coupling and (ir-) reversibility. Moreover, some separate categories which are included in AHP, can have an effect on distributional impacts on the different sectors, groups and regions. By AHP, the impacts of global dimensions and the spatial data can be compared independently. Furthermore AHP can cover social, environmental and economic impacts.

\section{Operational Aspects}

Some of the operational aspects are difficult to guesstimate and depend very highly on the subjects; for example applying the tools' costs and manpower needs. Generally, much data is required for estimating the effects and lots of expert judgment for explaining the results. For estimating operational aspects both quantitative and qualitative data can be combined.

The methodology for using AHP method is very clear and straightforward. The requirements for this approach are:

1) Complex calculations

2) Corresponding software supports

Sometime under the AHP process, irregularity in ranking may occur. But the sensitivity of analysis allows the experts to evaluate the ratings even if the weights of criteria were changed.

Risk modeling can be assisted using the AHP process. The relative modeling, instead of the unconditional probabilities and utilizing the risk adjusted values, can create new possibilities to support the decision taken.

AHP is not related to any specific time scale and no limitations exist in terms of geography.

\subsection{Neural Networks}

Neural networks consist of simple elements acting in collateral. These elements are inspired by biological nervous systems. The network task, as in nature, is specified by the connection between elements. By training a neural network, a peculiar function can be performed by regulating the connections' value (weights) between elements.

Generally, neural networks are regulated, or trained so a specific input leads to a particular target output. Figure 2 represents this situation, the networks based on the comparison between output and target is regulated, until the output of networks matches with the target. Typically, many target and input pairs are utilized to train a network. 


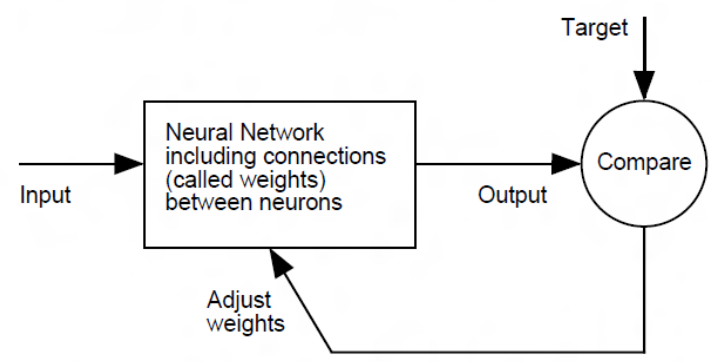

Figure 2. Supervised learning

There is one best known training in neural networks process which is called Batch training. Batch training is a process in which the weights and prepossess changes according to the whole set of input. Additional training is sometimes directed to as "adaptive" or "one line" training.

Neural networks are used in a variety of fields of applications like,
a) Identification
b) Speech
c) Pattern recognition
d) Classification
e) Control systems
f) Vision

Today, most of the problems which are difficult for arbitrary computers and human beings can be solved by neural networks.

Since the past five decades, the field of neural networks has been studied but it is just in the last 15 years that the strong and intense applications of this pattern are developing. The terms of neural networks differ from optimization and control system in which the basic mathematics have been established for many years (Demut and Beale, 2002).

\subsection{Conceptual Framework}

The conceptual framework is the basis of the whole research. It is a systematically designed and explained network of relations among the variables that appear in a research work (Sekaran, 2003). Figure 3 displays the schematic diagram that describes the relationships that exist among the variables in this study.

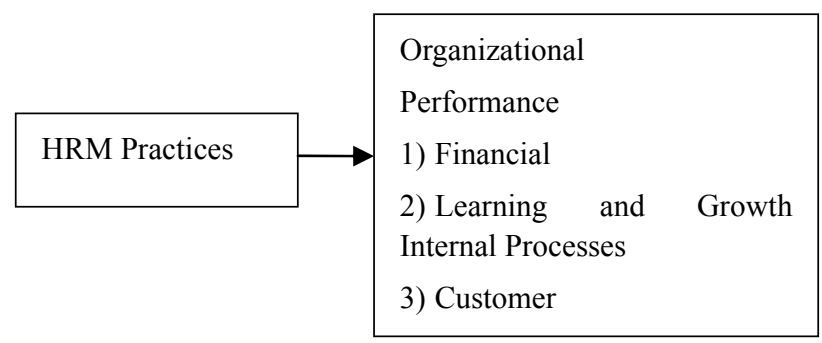

Figure 3. Conceptual framework
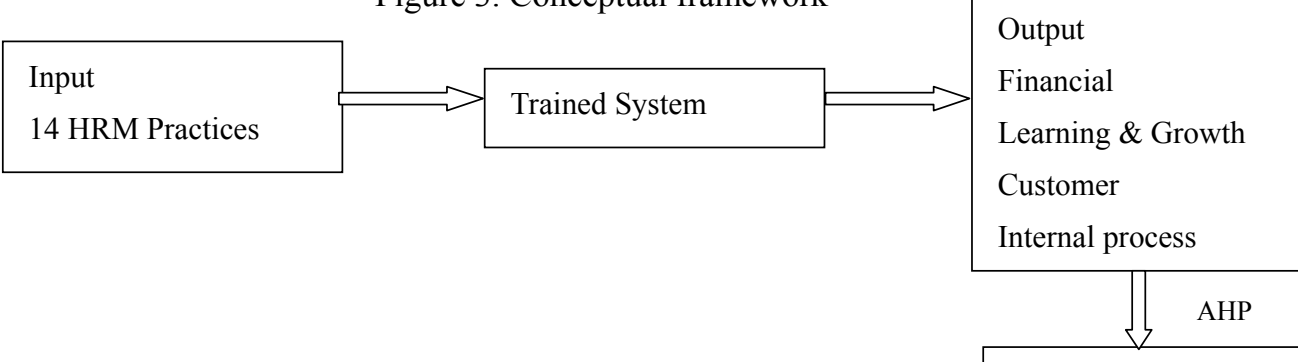

Figure 4. Research process

Best HRM practices 
The method of this study is concentrated on the four systems presented in Figure 4. The system has the capability to predict future (impact of each group of HRM practices). To clarify the above system, each part will be detailed:

\section{Input:}

As mentioned before and shown in Table 1, different scholars have highlighted different practices that may have an impact on performance.

Therefore, this study focuses on 14 HRM practices as follows:

1) Employment security: This practice is presumed to be flexible and it means that employees without any control are not quickly fired because of economic reduction or the senior management's strategic mistakes. This practice is totally concentrated on all employments rather than just supporting individuals for their behavior in their job (Morgan, 2001).

2) Selective in Recruiting: All organizations are very concerned about the people who are recruited to obtain profits for them, so the selective hiring procedure is one of the most crucial practices in organizations. Severe and difficult selections need a method, and it should be developed and refined through learning and feedback over time for ensuring that the organization can determine the skills which they are looking for in the applicants' pool (Pfeffer, 1998).

3) High Wages: Nowadays compensation plays an important role in any organization. The level of compensation and reward may lead the employees to be clearly valued and valuable for the organization. There are various types of compensation; the following are some of the examples:
a) Share ownership
b) Pay increases
c) Profit sharing
d) Stock options
e) Paying for skills (Morgan, 2001)

4) Incentive Pay Based on Performance Appraisal: In most high performance work systems, conditional compensation plays a significant role. This kind of compensation can take a variety of forms like:

a) Profit sharing

b) Various forms of individual or team incentives

c) Pay for skills

d) Gain sharing (Pfeffer, 1995)

5) Employee Ownership: This practice is another form of financial incentives which is designed to equal the employees' interests with shareholders. (Huselid, 1995)

6) Information Sharing: For inducing trust in the people who work for an organization, sharing information such as strategy, financial performance and operational measures are very significant and vital. Just training and motivating employees without sharing information with them cannot lead the organization to gain competitive advantage through their people (Morgan, 2001).

7) Participation and Empowerment: This practice supports the decentralization of worker participation, decision making and empowerment for controlling the process of working (Pfeffer, 1995).

8) Self-Managed Teams: Most of the researchers found that workers with the self-managed teams have greater self-government, discretion and flexibility. In this way, employees have more opportunities to demonstrate and enhance their skills. This practice leads to job satisfaction and intrinsic rewards which results in out-performing of teams (Pfeffer, 1998).

9) Training and Skill Development: High performance management practices always involve employee skill development. Three most important components of high performance are (Pfeffer, 1998):
a) Training
b) Cross training
c) Cross utilization
10) Reduced Status Distinctions and Barriers: This practice includes: 
i) Dress

ii) Language

iii) Office management

iv) Wage differences across levels (Pfeffer, 1998)

11) Job Design: In this practice, the terms of the job are transparently and accurately explained (Delery \& Doty, 1996).

12) Promotion from Within: This practice involves monetary benefits and status rewards. Moreover, it enables a fair sense in the work place (Pfeffer, 1995).

13) Measurement of the HRM Practices: In this practice, the two most significant components of objectives which are attitude assessment and measurement are provided for having a successful feedback of HPWP system (Pfeffer, 1995).

14) Quality of Work/Life: There is a different explanation and definition for the terms of emotional, intellectual, or cultural satisfaction and material comfort in the routine life of every person. As Murphy in 2000 investigated, it is better to spend time with family rather than at work.

After the 14 practices mentioned above, it is essential to find out how to measure these practices. This study attempts to find out the level of the manager's belief in implementing each practice. Accordingly, Wright et al. (2005) questioned respondents in each work unit based on the nine particular HRM practices that appeared in their job classification; "Yes" answers were coded as 1; "No" answers were coded as zeros. "I don't know" answers were classified as "No" and coded as zeros. In other words, they defined a set and a map as shown below:

$$
\begin{aligned}
& \text { Set } X=\{\operatorname{Pr} \text { actice } 1, \operatorname{Pr} \text { actice } 2, \ldots, \operatorname{Pr} \text { actice } 9\} \\
& f: X \rightarrow\{0,1\}
\end{aligned}
$$

However, based on the fuzzy set theory, the above example (Lattice) and the method of Wright et al. (2005) can be replaced with a 7-point Likert scale ranging from 0 to 7 as follows:

$$
f: X \rightarrow\{0,1,2,3,4,5,6\}
$$

So, for each practice, respondent can choose any of these numbers that shows the intensity of implementation tendency of each practice. Regarding the obtained function, the mentioned 14 HRM practices, and Rule of Product, there are $7^{14}$ numbers of ways for choosing practices based on their intensities (Grimaldi, 1999).

\subsection{Neural Network Learning Process Termination Conditions}

A trained system is a neural network trained by certain inputs and outputs over and over again. The network will be trained by correcting the connectors' weights (which can also be called as the nodes' weights) to reduce the error rate in the learning stage. Reaching the desired error between the target and output, the aim of the iteration procedure is to adjust the weights. However, in many cases, this error is not determined. Furthermore, if the learning process continues for a very long time, the weights can be adjusted in the way that causes over fitting problem. This phenomenon occurs when the parameters and weights are adjusted very accurately on the training data which makes it vulnerable to generality. In many cases, if the parameters are adjusted very precisely with the training data, the performance on the test data or new data reduces because of having a different nature. It means that the performance for test data of new data would not be as good as what was achieved on the training data.

Therefore, to avoid infinite learning process or over fitting, several approaches can be adopted. In several cases, the learning process continues until specific number of iterations. In this approach, a number is simply pre-assigned for the termination criterion. The $\mathrm{NN}$ learning process will be stopped when it reaches this number. However, in most of cases, it is not possible to find a good approximation for this number. Besides, in many cases, it does not provide adequate results. The most popular approach is to check the error reduction in each process. If the error reduction remains unchanged or changed nontrivially for several number of iterations (which can be defined based on the complexity of the problem but mostly a small number of iterations can show this phenomena), the learning process stops. In this way, the number of iterations changes depending on the problem.

When a system is trained by an example, an important issue is how well it generalizes to the patterns outside the training set. For continuous domains, or large discrete ones, it is usually impossible to provide examples of every possible input. If the system simply memorizes the training patterns, it may do quite well during training but fail 
miserably when presented with similar but slightly different inputs. One would like the system to generalize from the training samples to underlying function and give reasonable answers to novel input. A rule of thumb for obtaining good generalization is to use the smallest system that will fit the data. Unfortunately, it is usually not obvious what size is the best so a common approach is to train successively smaller networks until the smallest one is found that will learn the data. (Reed \& Mark, 1993).

\subsection{Measuring Performance (Outcome)}

As mentioned above, certain inputs and outputs are needed to train the neural network. Although four perspectives for outcomes are considered (BSC's perspectives), to measure the outcome, another method will be used based on expert lecturers in universities who have high qualification in research. At first, they are asked their opinions about measuring the performance in the same scale for four perspectives (7-pointLikert scale based on their perception). After that, this scale will be applied (adapted) in measuring the performance of any industry.

\subsection{AHP Method for Identifying the Best Practices}

After training the mentioned neural network, the top manager (or CEO) will highlight the weight of each perspective of performance based on the needs or goals of the company, and also suggest some groups of practices with different intensities (7-point Likert scale). By entering the practices as fuzzy inputs, the trained system will show (forecast) the performance in all four perspectives. The obtained results will demonstrate different intensities in each perspective, so AHP method will contribute in choosing the best practices based on the highlighted weight.

\section{Conclusion}

Organizational performance may depend on structure and a firm's objectives. For example, Norton and Kaplan (1992) considered four perspectives for performance including Financial, Internal Process, Learning and Growth, and Customer.

While a quartet of perspectives for organizations is set out in the Balanced Scorecard by Norton \& Kaplan (2000), a company may choose not to develop in all four areas. Charity organizations, for example, may not aim to grow financially. Besides, priority of each of the perspectives may be different in different organizations. Besides, extant researches by famous scholars have shown HRM practices have potential effect on different aspects of performance. In this regard, this paper tried to present all the necessary concepts such as Fuzzy Logic, Neural Networks, and AHP method. The combination of the neural network with fuzzy inputs and AHP will be capable of forecasting the impacts of HRM practices on organizational performance. At first, one neural network should be trained by specific inputs and out puts, and after that, some groups of practices will be suggested by top managers. The trained NN will show the impacts of each group on the four perspectives of performance (BSC). At the end, the AHP method will highlight the most proper group of practices based on the goal of the company.

Previous researches utilized different theories such as human capital, social capital as well as resource-based review in order to increase organizational performance through using specific and limited HRM practices. However, this study considered 14 practices which almost can cover all of the practices in previous studies. On the other hand, this research verified previous investigations in order to present new and efficient methods.

Future researches can consider mentioned practices in order to focus on specific industries for example ICT or manufacturing industry.

\section{References}

Aghababa, S., \& Farzianpour, F. (2009). Hearth measurement in Malcolm Baldrige: 2009-2010 guidelines an dish aver, 12-42.

Ahmad, S., \& Schroeder, R. (2003). The impact of human resource management practices on operational performance: Recognizing country and industry differences. Journal of Operations Management, 21(1), 19-43. http://dx.doi.org/10.1016/S0272-6963(02)00056-6

Astor, L. (2009). HR Priorities in 2009: The Landscape Continues to Change, Astor Levin, and Brisbane. Retrieved April 23, 2010, from http://www.astorlevin.com

Barney, J. B. (1986). Strategic factor markets: Expectations, luck, and business strategy. Management Science, 42, 1231-1241. http://dx.doi.org/10.1287/mnsc.32.10.1231 
Barney, J. B. (1991). Firm resources and sustained competitive advantage. Journal of Management, 17(1), 99-120. http://dx.doi.org/10.1177/014920639101700108

Barney, J. B. (1995). Gaining and sustainable competitive advantage. New York: Addison-Wesly, Ch 5.

Barney, J. B. (1995). Looking inside for competitive advantage. Academy of Management Executive, 9(4), 49-61. http://dx.doi.org/10.5465/AME.1995.9512032192

Barney, J. B. (2001). Is the resource-based 'view' a useful perspective for strategic management research? Yes. Academy of Management Review, 26(1), 41-56. http://dx.doi.org/10.2307/259393

Barney, J. B., \& Wright, P. M. (1998). On becoming a strategic partner: The role of human resources in gaining competitive advantage. Human Resource Management, 37(1), 31-46. http://dx.doi.org/10.1002/(SICI) 1099-050X(199821)37:1<31::AID-HRM4>3.0.CO;2-W

Batt, R. (2002). Managing customer services: Human resource practices, quit rates and sales growth. Academy of Management Journal, 45(3), 587-598. http://dx.doi.org/10.2307/3069383

Boxall, P., \& Purcell, J. (2000). Strategic human resource management: Where have we come from and where should we be going? International Journal of Management Reviews, 2(2), 183-203. http://dx.doi.org/10. $1111 / 1468-2370.00037$

Boxall, P., Purcell, J., \& Wright, P. M. (2007). Human resource management: Scope, analysis and significance. In P. Boxall, J. Purcell, \& P. M. Wright (Eds.), The handbook of human resource management (pp. 1-16). Oxford: Oxford University Press.

Burris, S. N., \& Sankappanavar, H. P. (1981). A Course in Universal Algebra. Springer-Verlag. http://dx.doi.org/ $10.1007 / 978-1-4613-8130-3$

Chhinzer, N., \& Ghatheorde, G. (2009). Challenging Relationships: HR Metrics and Organizational Financial Performance. The Journal of Business Inquiry, 8(1), 37-48.

Collins, C. J., \& Clark, K. D. (2003). Strategic human resource practices, top management team social networks, and firm performance: The role of human resource practices in creating organizational competitive advantage. Academy of Management Journal, 46(6), 740-751. http://dx.doi.org/10.2307/30040665

Collins, C. J., \& Smith, K. G. (2006). Knowledge exchange and combination: The role of human resource practices in the performance of high-technology firms. Academy of Management Journal, 49(3), 544-560. http://dx.doi.org/10.5465/AMJ.2006.21794671

Combs, J., Liu, Y., Hall, A., \& Ketchen, D. (2006). How much do high performance work practices matter? A meta-analysis of their effects on organizational performance. Personnel Psychology, 59(3), 501-528. http://dx.doi.org/10.1111/j.1744-6570.2006.00045.x

Datta, K., Guthrie, J., \& Wright, P. (2003). HRM and Firm productivity: Does industry matter'. Presented in National Academy of Management Meetings, WA.

Davision, W. N., Worrell, D. L., \& Fox, J. B. (1996). Early retirement programs and firm performance. Academy of Management Journal, 39(4), 970-984. http://dx.doi.org/10.2307/256719

Delery, J. E. (1998). Issues of fit in strategic human resource management: Implications for research. Human Resource Management Review, 8(3), 289-309. http://dx.doi.org/10.1016/S1053-4822(98)90006-7

Delery, J. E., \& Doty, D. H. (1996). Modes of theorizing in strategic human resource management: Tests of universalistic, contingency, and configurationally performance predictions. Academy of Management Journal, 39(4), 802-835. http://dx.doi.org/10.2307/256713

Demut, H., \& Beale, M. (2002). Neural Nework Toolbox for use MATLAB. TheMathWorks, Inc.

Dyer, L., \& Reeves, T. (1995). HR strategies and firm performance: What do we know and where do we need to go. International Journal of Human Resource Management, 6(3), 656-670. http://dx.doi.org/10.1080/ 09585199500000041

Finney, J. (2008). Six secrets of top performers. Communication World, 25(3), 23.

Grimaldi, R. P. (1999). Discrete and Combinatorial Mathematics, an Applied Introduction (5th ed.). Addison-Wesley.

Guthrie, J. P. (2001). High-involvement work practices, turnover, and productivity: Evidence from New Zealand. Academy of Management Journal, 44(1), 180-190. http://dx.doi.org/10.2307/3069345 
Hebert, P. (2004). Prospecting the future. CIM Bulletin, 97(1082), 32.

Hojabri, R. (2011). Study on evaluation systems for healthcare organization. TaleePoyesh, 55-122.

Huselid, M. A. (1995). The impact of human resource management on turnover, productivity, and corporate financial performance. Academy of Management Journal, 38(3), 635-672. http://dx.doi.org/10.2307/256741

Huselid, M. A., \& Becker, B. E. (1996). Methodological issues in cross-sectional and panel estimates of the HR-firm performance link. Industrial Relations, 35(3), 400-422. http://dx.doi.org/10.1111/j.1468-232X. 1996.tb00413.x

Huselid, M. A., Beatty, R. W., \& Becker, B. E. (2005). "A players" or "A positions"? The strategic logic of workforce management. Harvard Business Review, 110-117.

Huselid, M. A., Jackson, S. E., \& Schuler, R. S. (1997). Technical and strategic human resource management effectiveness as determinants of firm performance. Academy of Management Journal, 40(1), 171-188. http://dx.doi.org/10.2307/257025

Ichniowski, C., (1990). Manufacturing businesses. NBER Working Paper series, 3449, National Bureau of Economic Research. Cambridge, MA.

Ichniowski, C., Shaw, K., \& Prennushi, G. (1997). The effects of human resource management practices on productivity: A study of steel finishing lines. The American Economic Review, 87(3), 219-313.

Ichniowski, C., Thomas, K., David, L., Craig, O., \& George, S. (1996). What Works at Work: Overview and Assessment. Industrial Relations, 35, 299-333. http://dx.doi.org/10.1111/j.1468-232X.1996.tb00409.x

Kalleberg, A. L., \& Moody, J. W. (1994). Human resource management and organizational performance. American Behavioural Scientist, 37, 948-962. http://dx.doi.org/10.1177/0002764294037007007

Kaplan, R. S. \& Norton. D. P. (1992). The balanced scorecard - Measures that drive performance. Harvard Business Review, 71-79.

Kaplan, R. S., \& Norton, D. P. (2000). Having trouble with your strategy? Then map it. Harvard Business Review, 1-10.

Kaplan, R., \& Norton, D. (1996). The balanced scorecard. Harvard Business Press.

Kaplan, R., \& Norton, D. (2001). The strategy focused organization. Harvard Business Press.

Khatri, N. (2000). Managing human resource for competitive advantage: A study of companies in Singapore. International Journal of Human Resource Management, 11(2), 336-365. http://dx.doi.org/10.1080/09585 1900339909

Kulik, C. T., \& Bainbridge, H. T. J. (2006). HR and the line: The distribution of HR activities in Australian organisations. Asia Pacific Journal of Human Resources, 44(2), 240-256. http://dx.doi.org/10.1177/1038 411106066399

Leana, C. R., \& Van Buren, H. J. (1999). Organizational social capital and employment practices. Academy of Management Review, 24(3), 538-555. http://dx.doi.org/10.2307/259141

Lengnick-Hall, C. A., \& Lengnick-Hall, M. L. (1988). Strategic human resources management: A review of the literature and a proposed typology. Academy of Management Review, 13(3), 454-470. http://dx.doi.org/10. $2307 / 258092$

Lengnick-Hall, M. L., Lengnick-Hall, C. A., Andrade, L. S., \& Drake, B., (2009). Strategic human resource management: The evolution of the field. Human Resource Management Review, 19(3), 64-85. http://dx.doi. org/10.1016/j.hrmr.2009.01.002

Lepak, D. P., \& Shaw, J. (2008). Strategic HRM in North America: A look to the future. International Journal of Human Resource Management, 19(8), 1486-1499. http://dx.doi.org/10.1080/09585190802200272

Lepak, D. P., \& Snell, S. A. (2002). Examining the human resource architecture: The relationships among human capital, employment, and human resource configurations. Journal of Management, 28(4), 517-543. http://dx.doi.org/10.1016/S0149-2063(02)00142-3

Lepak, D. P., Liao, H., Chung, Y., \& Harden, E. E. (2006). A conceptual review of human resource management systems in strategic human resource management research. In J. J. Martocchio (Ed.), Research in personnel and human resource management (Vol. 25, pp. 217-271). Greenwich, CT: JAI Press. 
Liao, H., Toya, K., Lepak, D. P., \& Hong, Y. (2009). Do they see eye to eye? Management and employee perspectives of High-Performance Work Systems and influence processes on service quality. Journal of Applied Psychology, 94(2), 371-391. http://dx.doi.org/10.1037/a0013504

MacDuffie, J. P. (1995). Human resource bundles and manufacturing performance: organizational logic and flexible production systems in the world auto industry. Industrial and Labour Relations Review, 48(2), 197-221. http://dx.doi.org/10.2307/2524483

Morgan, J. P. (2001). HR practices for high-performance organizations, Foundation for sustainable economic development. Retrieved July 28, 2003, from http://www.fsed.org/researchprojects/project3a.html

Murphy, B., Herrman, H., Hawthorne, G., Pinzone, T., \& Evert, H. (2000). Australian WHOQoL instruments: User's manual and interpretation guide. Australian WHOQoL Field Study Centre, Melbourne, Australia.

Pfeffer, J. (1994). Competitive advantage through people. Boston, MA: Harvard Business School Press.

Pfeffer, J. (1998). The Human Equation: Building Profits by Putting People First. Boston: Harvard Business School Press.

Pfeffer, J., \& Davis-Blake, A. (1987). Understanding organizational wage structures: A resource dependence approach. Academy of Management Journal, 30(3), 437-455. http://dx.doi.org/10.2307/256008

PWC. (2009). Global CEO Survey - the Importance of Human Resources. Price Waterhouse Coopers, London. Retrieved March 9, 2010, from http://www.pwclegal.com.au

Reed, R., \& Robert, J. M. (1993). Neural Smithing: Supervised Learning in Feed forward Artificial Neural Networks. Retrieved from http://www.amazon.com/Neural-Smithing-Supervised-Feedforward-Artificial/ $\mathrm{dp} / 0262181908$

Saaty, T. L. (1980). The Analytic Hierarchy Process. New York: McGraw Hill. International, Translated to Russian, Portuguese, and Chinese, Revised editions, Pittsburgh: RWS Publications.

Saaty, T. L. (1982). Decision Making for Leaders; the Analytical Hierarchy Process for Decisions in a Complex World. Belmont, CA: Wadsworth. Translated to French, Indonesian, Spanish, Korean, Arabic, Persian, and Thai, latest edition, revised, (2000), Pittsburgh: RWS Publications.

Saaty, T. L. (1994). How to make a decision: The analytic hierarchy process. Interfaces, 24(6), 19-43. http://dx.doi.org/10.1287/inte.24.6.19

Saaty, T. L. (2005). Theory and Applications of the Analytic Network Process. Pittsburgh, PA: RWS Publications.

Saaty, T. L., \& Alexander, J. (1989). Conflict Resolution: The Analytic Hierarchy Process. New York: Praeger.

Saaty, T. L., \& Forman, E. H. (1993). The Hierarchon - A Dictionary of Hierarchies. Pittsburgh, PA: RWS Publications.

Saaty, T. L., \& Kearns, K. (1985). Analytical Planning; the Organization of Systems. Oxford: Pergamon Press. Translated to Russian (1991). Reprinted (1991) Pittsburgh: RWS Publications.

Saaty, T. L., \& Ozdemir, M. (2005). The Encyclical. Pittsburgh, PA: RWS Publications.

Saaty, T. L., \& Vargas, L. G. (1982). The Logic of Priorities; Applications in Business, Energy, Health, and Transportation. Boston: Kluwer-Nijhoff. Reprinted in Paperback (1991), Pittsburgh: RWS Publications.

Saaty, T. L., \& Vargas, L. G. (1991). Prediction, Projection and Forecasting. Boston: Kluwer Academic. http://dx.doi.org/10.1007/978-94-015-7952-0

Saaty, T. L., \& Vargas, L. G. (2006). Decision Making with the Analytic Network Process: Economic, Political, Social and Technological Applications with Benefits, Opportunities, Costs and Risks. New York: Springer.

Saaty, T. L., \& Vargas, L.G. (2000). Models, Methods, Concepts and Applications of the Analytic Hierarchy Process. Boston: Kluwer Academic Publishers.

Sekaran, U. (2003). Research Method for Business, A Skill Building Approach (4th ed.). New York: John Wiley $\&$ Sons.

Sun, L., Aryee, S., \& Law, K. S. (2007). High-performance human resource practices, citizenship behaviour, and organizational performance: a relational perspective. Academy of Management Journal, 50(3), 558-577. http://dx.doi.org/10.5465/AMJ.2007.25525821 
Takeuchi, R., Lepak, D. P., Wang, H., \& Takeuchi, K. (2007). An empirical examination of the mechanisms mediating between high-performance work systems and the performance of Japanese organizations. Journal of Applied Psychology, 92(4), 1069-1083. http://dx.doi.org/10.1037/0021-9010.92.4.1069

Ulrich, D., Losey, M. R., \& Lake, G. (1997). Tomorrow's HR Management. Wiley, New York.

Uysal, G. (2008). Relationship among HR and firm performance: Turkey content. The Journal of American Academy of Business, 13(2), 77.

Wright, P. M., \& McMahan, G. C. (1992). Theoretical perspectives for strategic human resource management. Journal of Management, 18(2), 295-320. http://dx.doi.org/10.1177/014920639201800205

Wright, P. M., \& Snel, S. A. (1991). Toward an integrative view of strategic human resource management, Human Resources Management Review, 1, 203-225. http://dx.doi.org/10.1016/1053-4822(91)90015-5

Wright, P. M., Dunford, B. B., \& Snell, S. A. (2001). Human resources and the resource based view of the firm. Journal of Management, 27(6), 701-721. http://dx.doi.org/10.1177/014920630102700607

Wright, P. M., Gardner, T. M., \& Moynihan, L. M. (2003). The impact of HR practices on the performance of business units. Human Resource Management Journal, 13(3). http://dx.doi.org/10.1111/j.1748-8583.2003. tb00096.x

Wylie, J. (2005). The ideal antidote to shrinking margins - doing more with your existing assets and people. Engineering and Mining Journal, 206(6), 58.

Yanzhen, H. E., Ying, L. I. N., \& Meiming, W. U. (2010). The Effect on Organizational Performance by Human Resource Management ractices: Empirical Research on Chinese Manufacturing Industry, Fund Project: Supported by Program for National Natural Science Foundation.

Youndt, M. A., Snell, S. A., Dean, J. W., \& Lepak, D. P. (1996). Human resource management, manufacturing strategy, and firm performance. Academy of Management Journal, 39(4), 836-866. http://dx.doi.org/10. 2307/256714

Youndt, M. A., Subramaniam, M., \& Snell, S. A. (2004). Intellectual capital profiles: An examination of investments and returns. Journal of Management Studies, 41(2), 335-361. http://dx.doi.org/10.1111/j.14676486.2004.00435.x

Zimmermann, H. Y. (2001). Fuzzy set theory-and its applications (4th ed.). Kluwer. http://dx.doi.org/10.1007/ 978-94-010-0646-0

\section{Note}

Note 1. The Strategy- focused organization, Norton and Kaplan, 2000.

\section{Copyrights}

Copyright for this article is retained by the author(s), with first publication rights granted to the journal.

This is an open-access article distributed under the terms and conditions of the Creative Commons Attribution license (http://creativecommons.org/licenses/by/3.0/). 